\title{
14
}

\section{Cooperation in Jesús de Machaca in Bolivia}

\author{
José Blanes Jiménez and Edgar Antonio Pabón
}

\section{Context}

Through its European Union-funded project, Intercultural Conflicts, a democratic and participative regional response from Bolivia, Ecuador and Peru, the Centro Boliviano de Estudios Multidisciplinarios (CEBEM) established a cooperation programme with other institutions in Ecuador and Peru oriented towards strengthening the capacities of indigenous peoples and their leaders in the management of their territories. The programme takes place in the particular context of increasing indigenous movements in the region and in the critical moments following the public murder and burning of two mayors of Aymaran regions.

Under the coordination of CEBEM, support for municipal management of indigenous communities formed in the previous year was chosen as a key project objective in Bolivia. CEBEM signed a cooperation agreement with the Municipality of Jesús de Machaca to develop a research project, together with the indigenous authorities, to strengthen institutions and spread their experiences. This included building a website, conducting studies of the economy, strengthening the work of community roundtables in the developing operating plans and the systematization of their first experiences as a municipality. The project not only supported this particular experience of the Indigenous Municipality Jesús de Machaca, but sought to disseminate that experience and share the lessons learned with other municipalities in the area, in the Andean region, with the academic world and international cooperation, as well as with the national and regional public sector.

The general objective of the project was to build capacity for territorial management on the part of the authorities and their organizations. The project sought to consolidate democratic governance, strengthen interculturality and the protection of rights of the indigenous peoples, as a mechanism for the prevention and resolution of conflicts that affect indigenous populations in Bolivia, Ecuador and Peru.

As secondary objectives, the project sought to:

- implement tools to assist municipal and Aboriginal territorial management including geographic information systems (GISs), a study of municipal GDP, and a system of community roundtables for the elaboration of the annual operational plan (POA); 
- produce a book on the municipality, featuring writing by the people themselves and community leaders on their territories, culture and organization, the constitution of the municipality and its first administration, studies on natural resources and the impact of climate change on their economies.

- develop local and regional actions for research, the generation of public policy proposals to promote interculturality, the training of community leaders, authorities and functionaries, the exchange of experiences to strengthen the bonds between the organizations of the three countries and the creation of an Andean observatory.

Strengthening the municipal capacity for territorial management in cultural, economic, social, administrative and political terms is an important challenge in Bolivia. This is in line with political changes in the country that began with the 1994 Popular Participation Law, a law that created the rural municipalities. In the years 2003-07, a period of political changes tended to more strongly incorporate indigenous peoples in the new political constitution of the state. This culminated in the approval of the new Political Constitution in January 2009. This document established a system of autonomy for indigenous communities, which is understood by the government to be an alternative form of management of the territory, instead of the municipality.

In December 2009 the municipality approved a referendum to constitute itself in an Aboriginal Indigenous Peasant Autonomy. Many issues were important in resolving the challenges of indigenous territorial management within the framework of state reform and market development, including:

- social management of the territory in accordance with ancestral traditions;

- strengthening indigenous authorities for indigenous municipal management;

- strengthening local economic participants to improve economic integration in local and regional markets.

In the context of the aforementioned changes, the issue of greatest relevance registered in the last years in Bolivia and in the countries of the Andean region was that of interculturality and its relation to territorial management.

\section{Organization/structure}

This project was approved by the indigenous peoples, peasants and Aboriginals of three countries: Ecuador, Peru and Bolivia. Within this framework, each country had to choose a place of implementation and establish a three-year work strategy.

CEBEM had previously developed studies on citizen participation for the purpose of social and institutional reforms in Jesús de Machaca. Working from a foundation of mutual trust, CEBEM and the highest local authority (cabildo) discussed the main challenges to carrying out municipal management and, at the same time, maintaining social management and Aboriginal policies. Working groups of national and regional government functionaries and authorities, NGOs and international cooperation experts were organized. As a result of these 
workshops, an action plan was developed and revised each year between 2006 and 2008.

The objectives of the plan and its advances were disseminated, discussed and contrasted with the experiences of leaders of the other countries in workshops that took place in Bolivia, Peru and Ecuador over the years 2006-09.

The project consisted of a coordinating committee made up of technicians from the three countries. At the Bolivian level, CEBEM formed a team of local experts, with people from the municipality, for the development and implementation of the activities. Permanent coordination between the technical committee, the municipality and the cabildowas established. To this end, periodic meetings were arranged for consultation and information. CEBEM provided technical support and training, while the municipality and the cabildo implemented community roundtables, gathered information, put up the webpage and designed a book. Staff of other NGOs working in the municipality were trained to collaborate in these activities.

The support of other NGOs in the municipality was relied upon for several other special actions, along with the authorities and technicians of the municipality. Participants were identified for fieldwork in the 120 communities and a person was delegated to represent the cabildo in planning, decision making and organization of fieldwork. This person liaised with the community radio broadcasts and acted as a Spanish-Aymara interpreter. For its part, CEBEM dedicated three full-time researchers to the project: a coordinator, an expert in local development, an expert in education and training and an information technology staff person. Experts in the design and implementation of training courses, educators and communications specialists and designers were also hired temporarily for three research projects.

It was important that the work continue once the project finished. To this end, all the partners became strategic partners in the work process, which allowed for other opportunities and assets derived from their capacities, experiences and abilities. Of particular emphasis was the establishment and deepening of connections with other NGOs on the application and exercise of rights related to territorial management. Among the principal partners were: Centro de Comunicación y Desarrollo Andino (CENDA), Investigación Social y Asesoramiento Legal Potosí (ISALP), Capitanía del Alto y Bajo Izozo (CABI), la Fundación Machaca, ONG, Comunidad Andina Suma Satawi (CASSA), Veterinarios Sin Fronteras,and Servicios Múltiples de Tecnologías Agropecuarias (SEMTA).

\section{Activities}

Over three years (2006-09), six months were used to facilitate the objectives and action plan approved by the communities, two years for implementation, and another six months for the presentation of results and the publication and their systematization.

Although the EU project has ended, a series of activities continue in the shape of collaboration between CEBEM and the municipality with the aim of identifying 
steps for collaboration, investments, webpage development and intercultural dialogues through the Intercultural Relations Platform, in which other institutions of the region and from the North could participate.

The key moments of the project were the following:

- discussion of objectives, planning the activities and the timeline for their approval by the cabildo;

- education and training in the communities and for authorities on issues of indigenous norms, on public municipal administration and business management. This was an important step in the elaboration and start-up of the roundtables for the development and approval of the operational plan of the municipality. This was the first intercultural encounters among the three countries;

- the third step was finalizing the education and training with other municipalities, systematizing what was learned, the writing of a book on the municipality and disseminating the experience in the Andean region through virtual courses.

\section{Outcomes}

Participatory budgets were approved and a methodology for public engagement and consultation was established. The municipality has systems for the management of community roundtables for the municipal development of the social and economic sectors. More than 300 community members and their authorities have participated in the process of identification of local development priorities, the selection of priority projects agreed upon among the 120 communities; this is an exercise in the distribution of resources by consensus. Three operational plans were approved and disseminated in all of the participating 120 communities and 5,000 leaflets with information on the agreed-upon projects, their financing and the legal and municipal documents for their implementation were distributed.

The exercise was repeated after three years and has left a precedent for the following administrations.

\section{Training materials}

More than 10,000 copies of printed training materials were distributed in communities. Over 2,000 community members were trained in issues of municipal management, business management, environment and natural resources. One thousand women were trained in their functions for gender parity leadership as is the norm in indigenous territory. Each male authority has a female counterpart, generally his wife, who accompanies him in an equal manner in the process of decision making.

\section{Radio programmes}

Ten radio programmes that can be rebroadcast in Aymara on issues related to municipal management, business management, caring for the environment, ecologically sound production and the importance of women's participation in 
communal, municipal and economic management, especially in the sectors of education and health have been produced.

\section{Geographical information system}

A GIS that references the socio-demographic data to the geography of the communities and maps for each of the populated centres has been developed. The system can be expanded to include educational and health establishments, aquatic resources, roads and other public works. It is a valuable system as a baseline for planning as a visual tool for decision making in communities.

\section{Webpage}

The webpage is driven and maintained by community members and has documentary information on their territory, history, culture, social and economic conditions and municipal management. Its main sections are history, the cabildo, the municipal council, religion, economics, tourism, infrastructure and projects.

The webpage of Jesús de Machaca is the window to the intercultural dialogue between this town and others in Bolivia, the region and outside Latin America (http://machaca.cebem.org/index_esp.php).

\section{Book: Aboriginal Indigenous Aymara Municipality Jesús de Machaca}

This book, widely distributed among the 120 communities, is serving as a baseline for development planning and evaluation. The book brings together the experience of the municipality about its own form of government and the search for recognition of its autonomy based upon local practices and customs without being tied to political parties. The book is not an academic publication but instead is written by the people of Machaca itself, rigorously looking to establish the base for an inclusive and just indigenous autonomy.

This book contributed a space of dialogue and exchange, where people present their culture, not to impose it, but instead to share it, and create a framework of interculturality with other peoples and ethnic groups in Bolivia. The book also includes a participatory economic study, undertaken in collaboration with the people of the community. It also includes a study on natural resources and a description of the flora and fauna. Finally, a study on climate change in peasant communities is included (see: http://machaca.cebem.org/index_esp.php).

\section{Virtual classroom and professional upgrading}

Three online courses of professional upgrading, each one lasting six weeks, have been given twice to a total of 300 regional students. Several issues have arisen from the research under way, such as indigenous norms and positive law, indigenous territorialities and the participation of indigenous women in municipal governments. These courses have established a space for discussion and diffusion of indigenous values and customs in dialogue, not only with other experts and politicians of the region but also among cultures within and outside the country. As a continuation of this experience a fourth course on the topic of the Andean Amazonian worldview has been developed. 